\title{
Transition Metal Free Sandmeyer-Type Reductive Disulfuration of
}

\section{Anilines}

\author{
Shiqi Chen, ${ }^{[a]}$ Si Cao, ${ }^{[a]}$ Chaoyang Liu, ${ }^{[a]}$ Baoxu Wang, ${ }^{[a]}$ Xiaorui Ren, ${ }^{[a]}$ Hang Huang, ${ }^{[a]}$ and Xi Wang ${ }^{*[a]}$
}

[a] S. Chen, S. Cao, C. Liu, B. Wang, X. Ren, H. Huang, Prof. Dr. X. Wang

College of Chemistry and Chemical Engineering, State Key Laboratory of Chemo/Biosensing and Chemometrics, Advanced Catalytic Engineering

Research Center of the Ministry of Education, Hunan University, Changsha 410082, P. R. China.

E-mail: cccewangxi@hnu.edu.cn

Abstract: A transition metal/ligand free disulfuration of anilines with disulfur transfer reagents (dithiosulfonate or tetrasulfide) is reported herein. The reaction, which can be considered as a reductive disulfuration variation of the classic Sandmeyer reaction, is performed under mild conditions and exhibits broad scope across aniline substrate and disulfur transfer reagent classes. The gramscale synthesis of disulfides is successfully achieved through this method, rendering the approach highly valuable.

Disulfide scaffolds are ubiquitous structural units in biological molecules. They serve as bridges to add additional stability to the 3D structure of proteins which are required for protein folding and function. ${ }^{[1]}$ In addition to the effect of disulfides in proteins, disulfides enjoy a privileged role in the realm of pharmaceuticals, ${ }^{[2]}$ food chemistry, ${ }^{[3]}$ and natural products (Scheme 1). ${ }^{[4]}$
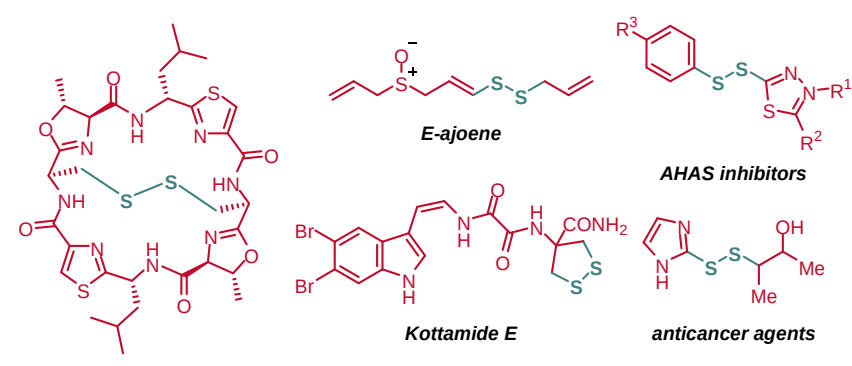

AHAS inhibitors

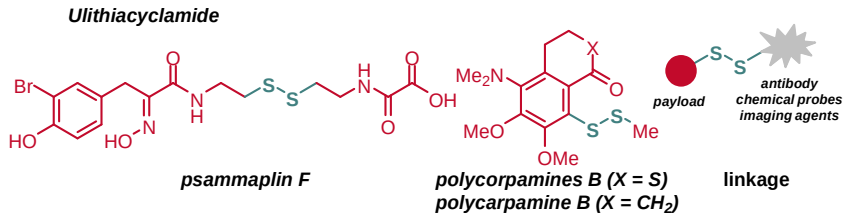

Scheme 1. Selected representative disulfides and their applications
Methods for synthesis of unsymmetric disulfides typically require oxidative activation of one of two different thiol precursors followed by nucleophilic substitution by another thiol. ${ }^{[5]}$ Recent representative progress on oxidative cross-coupling thiophenol and alkylthiol by Lei $^{[6 a-b]}$ and $\mathrm{JiaO}^{[\mathrm{fcc}]}$ involved the use of peroxide, air, as well as an electrochemical oxidant (Scheme 2a). Alternatively, Yamaguchi group have disclosed a rhodium-catalyzed disulfide exchange strategy for access to unsymmetric disulfides (Scheme 2b). ${ }^{[7]}$ Although prominent progress has been made to synthesis of unsymmetric disulfides through the construction of $S-S$ bond, ${ }^{[5]}$ these approaches are often 


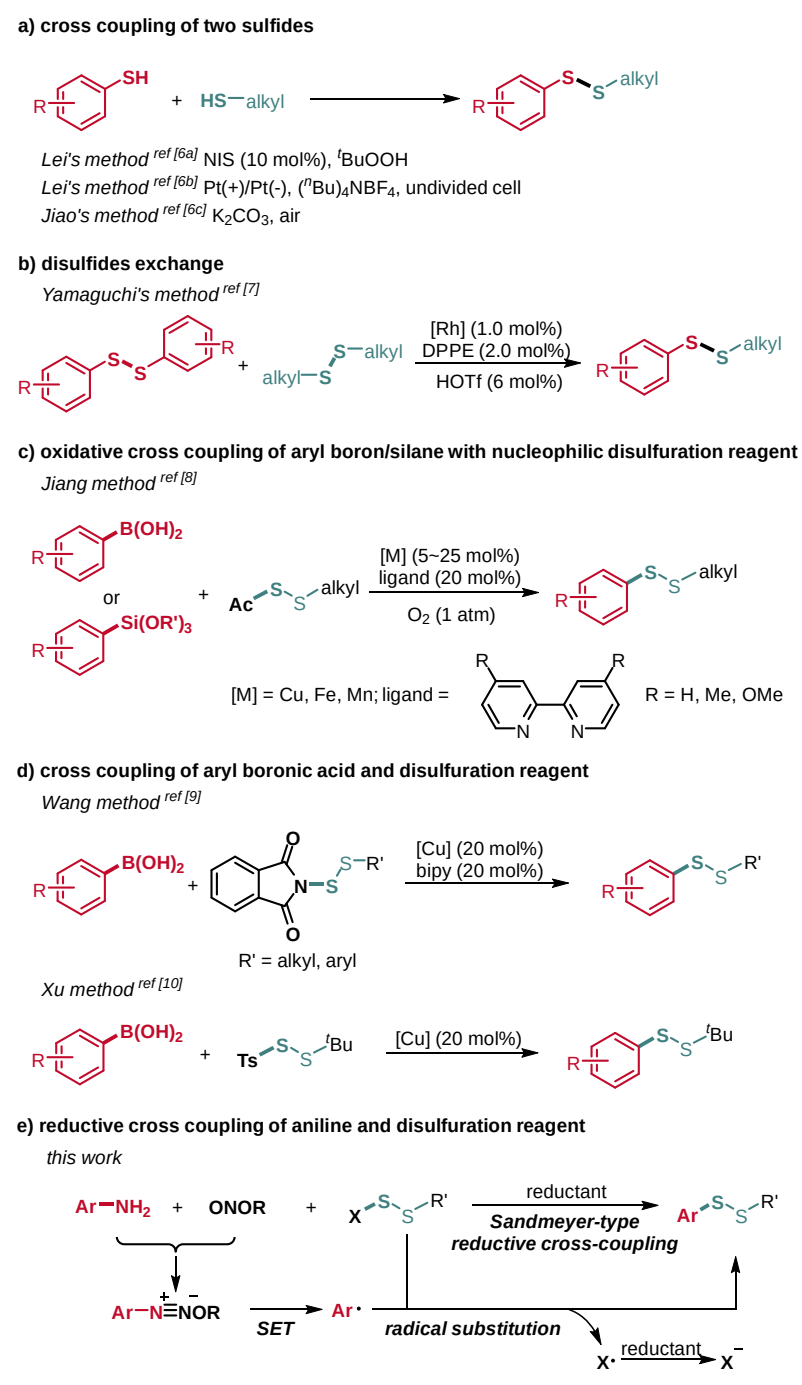

Scheme 2. Synthetic strategies for access to unsymmetrical aryl disulfides.

limited to a certain extent by at least one of the following points: starting materials are not easily available; homocoupling is unavoidable; overoxidation causes side reactions. In an attempt to overcome these limitations, prefunctionalized disulfur transfer reagents (X-SSR, X = Ac, PhthN, Ts, etc.) have been developed to directly transfer "-SSR" moieties onto substrates through the construction of C-SSR bonds ${ }^{[8-9]}$ Along these lines, Jiang and co-

Table 1. Reaction optimization.

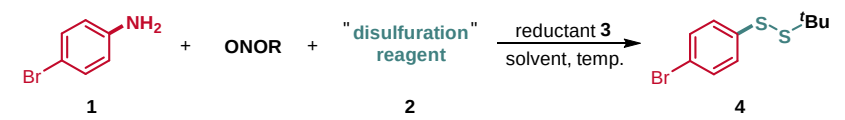

\begin{tabular}{|c|c|c|c|c|c|}
\hline $\begin{array}{c}\text { entry } \\
\quad a\end{array}$ & $\mathbf{R}$ & 2 & 3 & $\begin{array}{c}\text { solve } \\
\text { nt }\end{array}$ & $\begin{array}{l}\text { yield } \\
(\%)^{b}\end{array}$ \\
\hline
\end{tabular}

\begin{tabular}{|c|c|c|c|c|c|}
\hline $1^{c}$ & $\begin{array}{l}\text { tert- } \\
\text { butyl }\end{array}$ & $\begin{array}{l}2 \\
a\end{array}$ & none & $\mathrm{MeCN}$ & trace \\
\hline 2 & $\begin{array}{l}\text { tert- } \\
\text { butyl }\end{array}$ & $\begin{array}{l}2 \\
b\end{array}$ & none & $\mathrm{MeCN}$ & trace \\
\hline 3 & $\begin{array}{l}\text { tert- } \\
\text { butyl }\end{array}$ & $\begin{array}{l}2 \\
\mathrm{C}\end{array}$ & none & $\mathrm{MeCN}$ & trace \\
\hline 4 & $\begin{array}{l}\text { tert- } \\
\text { butyl }\end{array}$ & $\begin{array}{l}2 \\
\text { d }\end{array}$ & none & $\mathrm{MeCN}$ & 39 \\
\hline 5 & $\begin{array}{l}\text { tert- } \\
\text { butyl }\end{array}$ & $\begin{array}{l}2 \\
\text { d }\end{array}$ & $\mathrm{Na}_{2} \mathrm{~S}$ & $\mathrm{MeCN}$ & 33 \\
\hline 6 & $\begin{array}{l}\text { tert- } \\
\text { butyl }\end{array}$ & $\begin{array}{l}2 \\
\text { d }\end{array}$ & $\begin{array}{c}\mathrm{Na}_{2} \mathrm{~S} \\
\mathrm{O}_{3}\end{array}$ & $\mathrm{MeCN}$ & 46 \\
\hline 7 & $\begin{array}{l}\text { tert- } \\
\text { butyl }\end{array}$ & $\begin{array}{l}2 \\
\text { d }\end{array}$ & $\begin{array}{c}\mathrm{Na}_{2} \mathrm{~S}_{2} \\
\mathrm{O}_{3}\end{array}$ & $\mathrm{MeCN}$ & 26 \\
\hline 8 & $\begin{array}{l}\text { tert- } \\
\text { butyl }\end{array}$ & $\begin{array}{l}2 \\
\text { d }\end{array}$ & $\mathrm{S}_{8}$ & $\mathrm{MeCN}$ & 25 \\
\hline 9 & $\begin{array}{l}\text { tert- } \\
\text { butyl }\end{array}$ & $\begin{array}{l}2 \\
\text { d }\end{array}$ & $3 a$ & $\mathrm{MeCN}$ & 48 \\
\hline 10 & $\begin{array}{l}\text { tert- } \\
\text { butyl }\end{array}$ & $\begin{array}{l}2 \\
\text { d }\end{array}$ & $3 b$ & $\mathrm{MeCN}$ & 36 \\
\hline 11 & $\begin{array}{l}\text { tert- } \\
\text { butyl }\end{array}$ & $\begin{array}{l}2 \\
\text { d }\end{array}$ & $3 c$ & $\mathrm{MeCN}$ & 51 \\
\hline 12 & $\begin{array}{l}\text { tert- } \\
\text { butyl }\end{array}$ & $\begin{array}{l}2 \\
\text { d }\end{array}$ & $3 d$ & $\mathrm{MeCN}$ & 15 \\
\hline 13 & n-butyl & $\begin{array}{l}2 \\
\text { d }\end{array}$ & $3 c$ & $\mathrm{MeCN}$ & 29 \\
\hline 14 & $\begin{array}{l}\text { iso- } \\
\text { amyl }\end{array}$ & $\begin{array}{l}2 \\
\text { d }\end{array}$ & $3 c$ & $\mathrm{MeCN}$ & 32 \\
\hline 15 & $\begin{array}{l}\text { tert- } \\
\text { butyl }\end{array}$ & $\begin{array}{l}2 \\
\text { d }\end{array}$ & $3 c$ & DMF & 22 \\
\hline 16 & $\begin{array}{l}\text { tert- } \\
\text { butyl }\end{array}$ & $\begin{array}{l}2 \\
\text { d }\end{array}$ & $3 c$ & DCM & 16 \\
\hline 17 & $\begin{array}{l}\text { tert- } \\
\text { butyl }\end{array}$ & $\begin{array}{l}2 \\
\text { d }\end{array}$ & $3 c$ & DCE & 33 \\
\hline $18^{d}$ & $\begin{array}{l}\text { tert- } \\
\text { butyl }\end{array}$ & $\begin{array}{l}2 \\
\text { d }\end{array}$ & $3 c$ & $\begin{array}{c}\mathrm{MeC} \\
\mathbf{N}\end{array}$ & $68(65)$ \\
\hline $19^{e}$ & $\begin{array}{l}\text { tert- } \\
\text { butyl }\end{array}$ & $\begin{array}{l}2 \\
e\end{array}$ & $3 c$ & $\begin{array}{c}\text { MeC } \\
\mathbf{N}\end{array}$ & 83 \\
\hline $20^{d}$ & $\begin{array}{l}\text { tert- } \\
\text { butyl }\end{array}$ & $\begin{array}{l}2 \\
\text { d }\end{array}$ & $3 c$ & $\mathrm{MeCN}$ & 50 \\
\hline $21^{e,}$ & $\begin{array}{l}\text { tert- } \\
\text { butyl }\end{array}$ & $\begin{array}{l}2 \\
e\end{array}$ & $3 c$ & $\mathrm{MeCN}$ & 69 \\
\hline
\end{tabular}

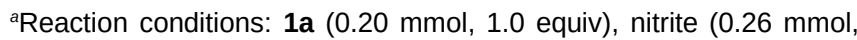
1.3 equiv), 2 ( $0.40 \mathrm{mmol}, 2.0$ equiv), 3 ( $0.40 \mathrm{mmol}, 2.0$ equiv), solvent $(2 \mathrm{~mL}), \mathrm{N}_{2}, 60{ }^{\circ} \mathrm{C}, 7 \mathrm{~h}$; ${ }^{b}$ Yield determined by $\mathrm{GC}$ analysis 
using $n$-dodecane as an internal standard. The value in parentheses refers to isolated yield. ' In the presence of $\mathrm{Na}_{2} \mathrm{CO}_{3}(0.40 \mathrm{mmol}, 2.0$ equiv). ${ }^{d}$ Reaction conditions: $1 \mathbf{1 a}(0.20 \mathrm{mmol}, 1.0$ equiv), nitrite $(0.52$ mmol, 2.6 equiv), 2 ( $0.50 \mathrm{mmol}, 2.5$ equiv), 3 ( $0.52 \mathrm{mmol}, 2.6$ equiv), solvent ( $2 \mathrm{~mL}), \mathrm{N}_{2}, 60{ }^{\circ} \mathrm{C}, 7 \mathrm{~h}$; ${ }^{e}$ Reaction conditions: $1 \mathrm{a}(0.20 \mathrm{mmol}$, 1.0 equiv), nitrite ( $0.36 \mathrm{mmol}, 1.8$ equiv), 2 ( $0.50 \mathrm{mmol}, 2.5$ equiv), 3 ( $0.52 \mathrm{mmol}, 2.6$ equiv), solvent $(2 \mathrm{~mL}), \mathrm{N}_{2}, 60^{\circ} \mathrm{C}, 7 \mathrm{~h}$; 'The reaction proceeded at room temperature instead of $60^{\circ} \mathrm{C}$.

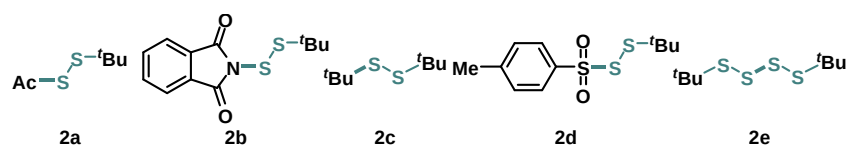

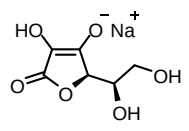

3a

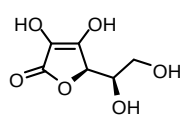

3b

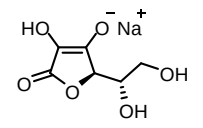

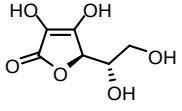

Figure 1. Disulfuration reagents and reductants tested.

workers have developed a novel nucleophilic reagent Ac-SSR applied in aryl unsymmetric disulfides synthesis via transition metal catalyzed (transition metal $=\mathrm{Cu}, \mathrm{Fe}, \mathrm{Mn}$ ) oxidative cross-coupling of arylboronic acid and Ac-SSR under oxygen atmosphere. ${ }^{\left[{ }^{[a]}\right.}$ Similarly, the same group also reported the oxidative cross-coupling of aryl silane and Ac-SSR (Scheme 2c) ${ }^{[8 b]}$ In the absence of oxidants, the direct copper-catalyzed disulfuration of aryl boronic acids with electrophilic disulfurating reagents $\mathrm{PhthN}-\mathrm{SSR}^{[0]}$ or Ts-SSR${ }^{[10]}$ have been reported by Wang and $\mathrm{Xu}$, independently (Scheme 2d). Though very useful, these appoaches commonly require transition metal catalyst (5 25 mol\%) and ligand (20 mol\%). Moreover, polysubstituted aryl and heteroaryl boronic acids could be rather expansive or even challenging to access. The development of novel and practical disulfuration transformation using other types of common and readily available aryl precursors would thus be of high value. Anilines as relatively cheap and readily available aryl sources, are commonly used in all sorts of coupling reactions through in situ generated aryl diazonium salts, which have been established as a series of classic methods for amino group converstion. ${ }^{[11-13]}$ Besides, anilines and protected anline derivatives, are easily functionalized via electrophilic aromatic substitution and $\mathrm{C}-\mathrm{H}$ functionalization strategies. ${ }^{[14]}$ The reductive cross-coupling of two electrophilic counterparts $^{[15,16]}$ to form unsymmetric disulfides is less studied by far, with the differentiation of the two electrophiles being a key challenge. In our proposed strategy, we envisioned that the aryl diazonium salt and the electrophilic disulfuration reagent could be effectively differentiated, where the aryl radical would be first generated through preferential SET (single electron transfer) reduction of the more oxidizing aryl diazonium salt, ${ }^{[17]}$ followed by radical substitution on the electrophilic disulfuration reagent to form the aryl disulfide product. Subsequently, the resulting radical $X$ would be further reduced by an excess amount of reductants. In this communication, we show a general and practical disulfuration of aniline under mild conditions without requiring any transition metal catalyst, ligand, and oxidant. Moreover, the amino group on anilines can be readily protected and deprotected, rendering this approach suitable for late-stage introduction of disulfide moieties onto an aromatic structure. The reaction is also a very rare example of reductive cross coupling in both Sandmeyer-type reactions ${ }^{[17 b, 18]}$ and disulfuration reactions (Scheme 2e).

We evaluated the feasibility of the proposed scheme in the reaction of 4-bromoaniline $\mathbf{1 a}$, nitrite, ${ }^{[19]}$ and disulfuration reagent (Table 1). An initial screening of disulfuration reagents, including nucleophilic reagent $\mathbf{2} \mathbf{a}$ in combination with sodium carbonate as the base ${ }^{[8 \mathrm{a}]}$ and other reagents ${ }^{[20]} \mathbf{2 b}$ and $\mathbf{2 c}$ proved discouraging (Table 1, entries 1-3), only Ts-SS ${ }^{t} B u \mathbf{2 d}^{[10]}$ giving the desired product 4 in a promising 39\% yield (entry 4). Concerning the electrophilicity of both aryl diazonium salt and $\mathrm{Ts}-\mathrm{SS}^{\mathrm{t}} \mathrm{Bu}$, we turned to screen reductants to promote the reductive cross coupling process. The efficiency was not conspicuously improved with inorganic reductants, such as sodium sulphide, sodium sulfite, sodium thiosulfate, and elemental sulfur (entries 5-8). To be gratified, organic reductants such as sodium erythorbate $\mathbf{3 a}$ and sodium ascorbate $\mathbf{3 c}$ provided positive results, whereas the homologous erythorbic acid $\mathbf{3 b}$ and vitamin C $\mathbf{3} \mathbf{d}$ did not (entries 9-12). A careful screen revealed that sodium ascorbate $3 c$ led to a significant improvement on yield of aryl disulfide 4 (entry 11). Next, we conducted a screen of nitrites, which demonstrated tert butyl nitrite still to be the most effective diazotization reagent for the conversion (entries 13 and 14). Other solvents were tested. However, in all cases a substantial loss in yield was noted (entries $15-17)$. Pleasingly, a distinct improvement of the yield to $68 \%$ (65\% isolated yield) was observed by further optimizing the amount and the ratio of tert-butyl nitrite, disulfuration reagent $\mathbf{2} \mathbf{d}$, and reductant $3 c$ (entry 18). Additionally, the reagent tetrasulfide $2 \mathbf{e}$ remarkably enhanced the reactivity, providing the desired 4 in $83 \%$ yield based on GC analysis. However, we failed to obtain the isolated yield of 4 because the resulting disulfide 4 and the remaining $2 e$ are mixed and inseparable by TLC (thin-layer chromatography) and column chromatography (entry 19). Ultimately, disulfuration at room temperature provided disulfide $\mathbf{4}$ with a lower efficiency (entries 2021). 
With optimized conditions identified, we explored the scope of the anilines 1 and disulfur transfer reagents 2 in reductive disulfuration (Table 2). The protocol succeeded with a variety of anilines bearing para-substituents, whereas the electronic perturbation of substituents had a distinct influence on the reaction efficiency. The conversion of 4-halogeno anilines and 4-trifluomethy aniline with $\mathbf{2 d}$ proceeded smoothly, delivering disulfides $\mathbf{4 a - 4 d}$ in moderate isolated yield. The anilines bearing the stronger electron withdrawing groups including acetyl, ester, cyano, nitro groups at para-position reacted with tetrasulfide $\mathbf{2 e}$, affording products $\mathbf{4 e - 4 h}$ in higher yields. To document the practicability, the disulfuration of aniline $\mathbf{1 f}$ on gram-scale gave desired product $\mathbf{4 f}$ in comparable yield as the small-scale experiment. Aniline, 4-phenyl aniline, and 4-tertbutyl aniline engaged in reactivity by using $\operatorname{Ts}^{-S S} S^{t} B u \mathbf{2 d}$, as the desired disulfides $\mathbf{4 i - 4 k}$ were formed in $40-61 \%$ isolated yield. In this protocol, as the same as the strong electron withdrawing groups, the electron donating groups, such as

Table 2. Substrate scope of reductive disulfuration..$^{a, b}$

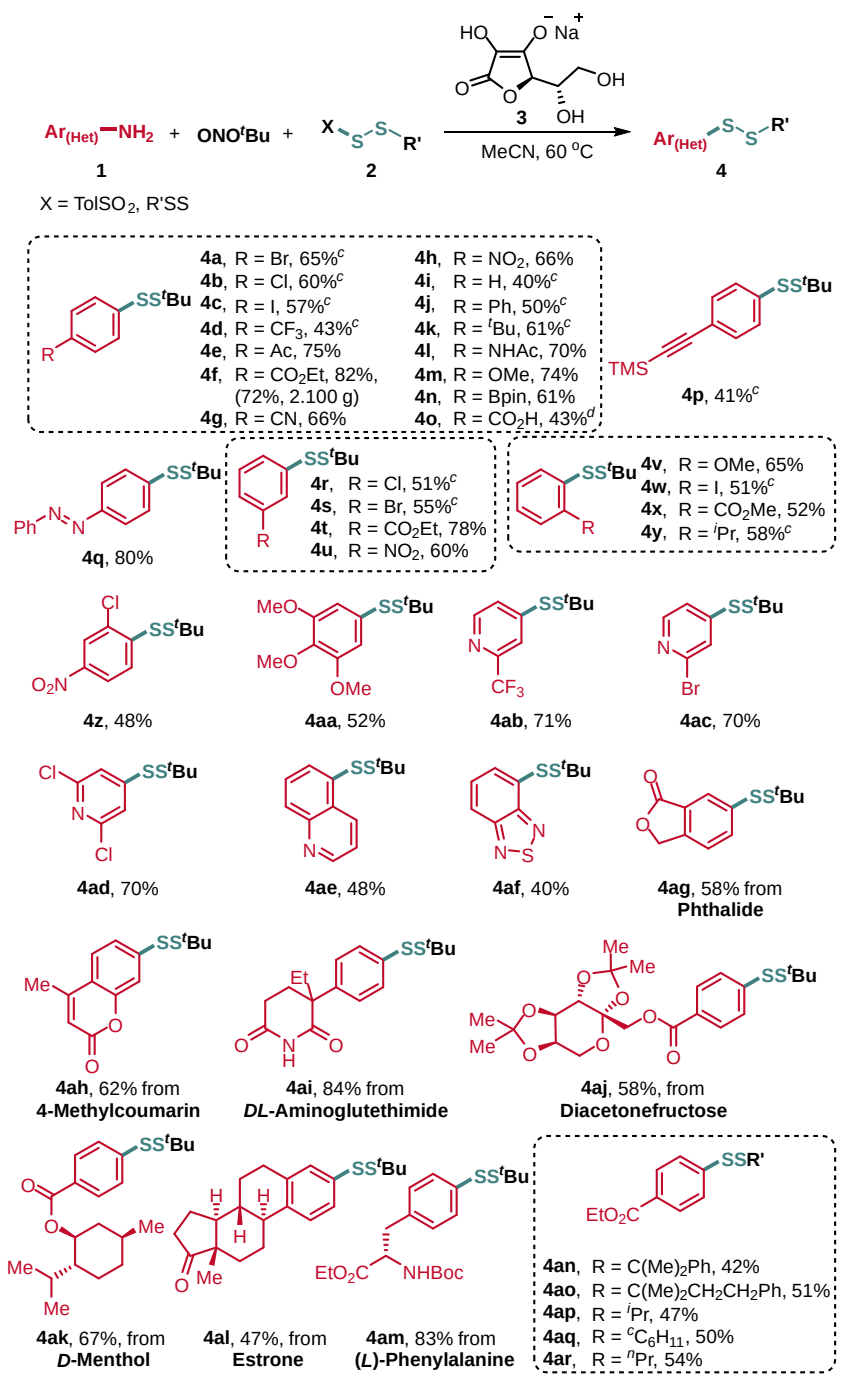

${ }^{a}$ Reaction condition A: $1(0.20 \mathrm{mmol}, 1.0$ equiv $)$, tertbutyl nitrite $(0.36 \mathrm{mmol}, 1.8$ equiv), 2e $(0.50 \mathrm{mmol}$, 2.5 equiv), 3c (0.52 mmol, 2.6 equiv), $\mathrm{MeCN}, \mathrm{N}_{2}, 60$ ${ }^{\circ} \mathrm{C}, 7 \mathrm{~h}$. ${ }^{b}$ Isolated yield. 'Reaction condition B: 1 (0.20 mmol, 1.0 equiv), tert-butyl nitrite $(0.52 \mathrm{mmol}, 2.6$ equiv), 2d (0.50 mmol, 2.5 equiv), 3c (0.52 mmol, 2.6 equiv), MeCN, $\mathrm{N}_{2}, 60{ }^{\circ} \mathrm{C}, 7 \mathrm{~h} .{ }^{\mathrm{d}} 4$-Aminobenzoic acid sodium salt was employed as the substrate.

acetamino and methoxy groups, also worked well to give $\mathbf{4 I}$ and $\mathbf{4 m}$ in good yields, respectively. Significantly, the mild conditions were tolerant of vulnerable functionalities, such as boronic ester, benzoate, alkynyl, phenylazo, delivering products $4 \mathbf{n}-\mathbf{4 q}$ Gratifyingly, these success results were mirrored with other anilines bearing meta-substituents $(\mathbf{4 r}-\mathbf{4 u})$. We next interrogated the electronic and steric effect of substitution on ortho-position of anilines. Electronic and steric modulations of the ortho-substituents have no obvious effect on the reactivity of the transformation Methoxy, iodo, ester, and iso-propyl groups were tolerated, providing disulfides $\mathbf{4 v - 4 y}$ in moderate yield. Furthermore, di- and multisubstituted disulfides $\mathbf{4 z}$ and $\mathbf{4 a a}$ were accessed in synthetically useful yield from extreme electron-poor and electron-rich anilines. Notably, the approach promoted the smooth synthesis of various Lewis basic $\mathrm{N}$-heterocyclic motifs with satisfactory yields (4ab-4af). To demonstrate the generality and practicability of this novel method applied in more complex molecules, we successfully converted the amino groups embedded in phthalide, 4-methylcoumarin, $D L$ aminoglutethimide, diacetonefructose, $D$-menthol, estrone and $L$ phenylalanine framework into disulfide groups (4ag-4am). Finally, with respect to disulfur transfer reagents as the coupling partners, both more bulky $-\mathrm{C}(\mathrm{Me})_{2} \mathrm{Ph}$ and $-\mathrm{C}(\mathrm{Me})_{2} \mathrm{CH}_{2} \mathrm{CH}_{2} \mathrm{Ph}$ and less bulky ${ }^{c} \mathrm{C}_{6} \mathrm{H}_{11},{ }^{i} \mathrm{Pr}$, ${ }^{n} \mathrm{Pr}$ substituted reagents behaved well, affording the anticipated products 4an-4ar in moderate yields.

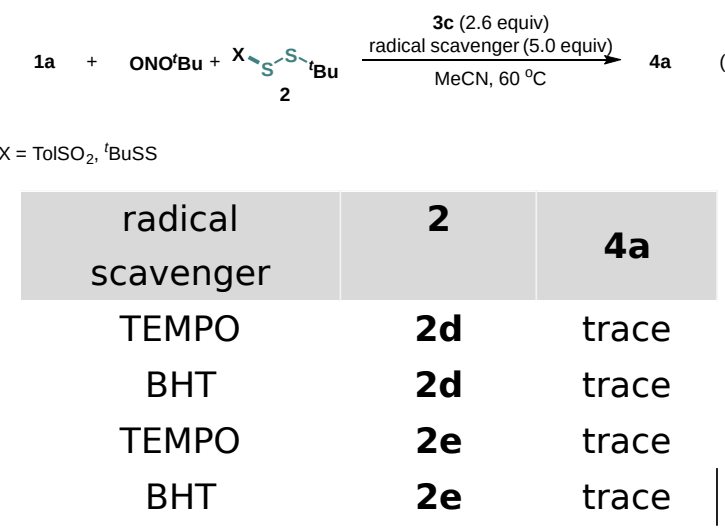




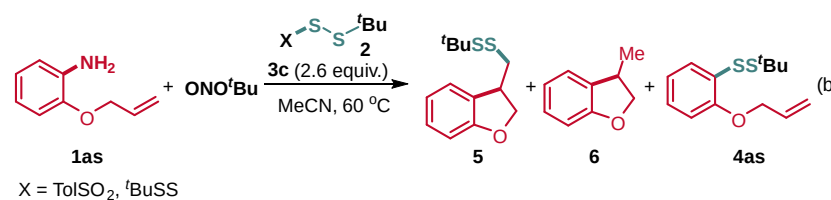

\begin{tabular}{|c|c|c|c|c|}
\hline 2 & 3 & 5 & 6 & 4as \\
\hline 2d & $3 c$ & $\begin{array}{c}30 \% \text { isolated } \\
\text { yield }\end{array}$ & ND. & ND. \\
\hline $2 e$ & $3 c$ & $\begin{array}{c}48 \% \text { isolated } \\
\text { yield }\end{array}$ & ND. & ND. \\
\hline $2 d$ & $\frac{3 \mathrm{c}(2.6 \text { equiv) }}{\mathrm{MeCN}, 60^{\circ} \mathrm{C}}$ & 2e $10 \%$ isolated yield & $+(60 \%$ remainin & ing 2d) \\
\hline $2 \mathrm{e}$ & $\frac{3 \mathrm{C}(2.6 \text { equiv) }}{\mathrm{MeCN}, 60^{\circ} \mathrm{C}}$ & no reaction $(95 \%$ rem & naining 2e) & \\
\hline or $2 \mathrm{e}$ & $\mathrm{MeCN}, 60^{\circ} \mathrm{C}$ & no re & & \\
\hline
\end{tabular}

Scheme 3. Mechanistic studies.

A set of experiments contributed to our current in-depth understanding of the reaction mechanism as well as the reactivity of the disulfuration reagents. Initially, the disulfurations of aniline 1a with $\mathbf{2} \mathbf{d}$ and $\mathbf{2 e}$ were shut down by addition of radical scavenger TEMPO (2,2,6,6-tetramethylpiperidine-1-oxyl) under standard conditions. The similar result was obtained by addition of another well-known radical trapping agent BHT (butylated hydroxytoluene) (Scheme 3a). To verify whether aryl radical is generated in the current reductive disulfuration process, a radical clock probe was introduced by using 2-(allyloxy)aniline 1as as the substrate. Under standard reaction conditions, the product $\mathbf{5}$ was formed in 30\% and $48 \%$ isolated yield through the radical cyclization/disulfuration sequence by using $T s-S S^{t} \mathrm{Bu} \mathbf{2 d}$ and ${ }^{t} B \mathrm{BSSSS}^{t} \mathrm{Bu} \mathbf{2 e}$ respectively, whereas the hydroarylation product 6 and the normal aryl disulfuration product 4as were not detected (Scheme $3 b$ ). Next, the control experiments showed that in the presence of the reductant $3 \mathrm{c}$ the reagent Ts-SStBu $2 \mathbf{d}$ was partly decomposed and converted (60\% remaining $\mathbf{2 d}$ ), resulting in formation of tetrasulfide $\mathbf{2 e}$ in $10 \%$ isolated yield (Scheme $3 \mathrm{c}$ ). However, reductant $3 \mathrm{c}$ was not able to reduce the reagent ${ }^{t} \mathrm{BuSSSS}{ }^{t} \mathrm{Bu} \mathbf{2 e}$ (>95\% remaining $2 \mathbf{2 e}$ ) under the same condition (Scheme $3 d$ ). In addition, both dithiosulfonate $\mathbf{2 d}$ or tetrasulfide $\mathbf{2} \mathbf{e}$ were thermally stable at reaction temperature in the absence of reductant 3 (Scheme $3 d$ and $3 e$ ). These results demonstrate that SET reduction of aryl diazonium salt to generate aryl radical is involved in the mechanism. Sodium ascorbate $3 \mathrm{c}$ acts as a reductive promoter to facilitate the formation of aryl radical and slow release of ${ }^{t} \mathrm{BuSSSS}{ }^{t} \mathrm{Bu}$ from Ts-SS ${ }^{t} \mathrm{Bu}$. It is possible that aryl radical undergoes radical substition with $\mathrm{Ts}^{-S^{t}} \mathrm{Bu}$ to form the disulfide 4.

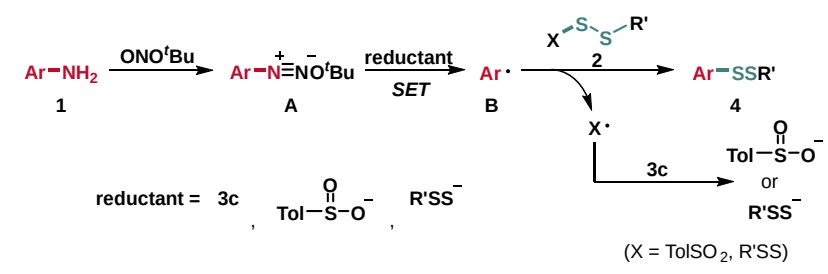

Scheme 4. Proposed mechanism

The mechanism of the reductive disulfuration is proposed to begin with SET reduction of in situ generated aryl diazonium salt $\mathbf{A}$ from aniline 1. The process was promoted by sodium ascorbate 3 and also by possible reductant $p$-tolylsulfinate (Ts) or disulfane anion (R'SS) to form the corresponding aryl radical $\mathbf{B}$ (Ar-), which subsequently undergoes radical substitution with dithiosulfonate or tetrasulfide to afford the disulfide 4. Meanwhile the radical substitution generates the corresponding $p$-tolylsulfonyl radical (Ts.) or disulfane radical (R'SS.), ${ }^{[21,}{ }^{22]}$ which is subsequently further reduced by sodium ascorbate $3 c$ to generate the reductive $p$ tolylsulfinate or disulfane anion (Scheme 4).

In conclusion, we have developed a novel reductive Sandmeyertype disulfuration of anilines using sodium ascorbate as a reductive promoter. Aryl and heteroaryl unsymmetric disulfides with a variety of substitution patterns can be accessed from readily available anilines under transition metal/ligand free and oxidant free conditions. The value of the method has been further proved by the compatibility with various complex structures and the feasibility of gram-scale synthesis. Expansion of substrate scope, synthetic application, and thorough mechanistic investigation will be of value to our group's ongoing efforts.

\section{Acknowledgements}

Financial support from the National Natural Science Foundation of China (Grant No. 22071048, Grant No. 21801073), the China Hunan Provincinal Science\&Technology Department (Grant No. 2018RS3044) are greatly appreciated.

Keywords: Sandmeyer-type reaction $\bullet$ diazonium salts $\bullet$ radical - disulfuration - reductive coupling 
[1] For reviews, see: a) Z. Cheng, J. Zhang, D. P. Ballou, C. H. Williams, Jr, Chem. Rev. 2011, 111, 5768; b) M. Góngora-Benítez, J. TullaPuche, F Albericio, Chem. Rev. 2014, 114, 901; For representative reports, see: c) M. Trabi, D. J. Craik, Trends Biochem. Sci. 2002, 27, 132; d) J. Alegre-Cebollada, P. Kosuri, J. A. Rivas-Pardo, J. M. Fernández, Nat Chem. 2011, 3, 882; e) T. Ilani, A. Alon, I. Grossman, B. Horowitz, E. Kartvelishvily, S. R. Cohen, D. Fass, Science 2013, 341, 74; f) E.-K. Bang, G. Gasparini, G. Molinard, A. Roux, N. Sakai, S. Matile, J. Am Chem. Soc. 2013, 135, 2088; g) C. Gehin, J. Montenegro, E.-K. Bang, A. Cajaraville, S. Takayama, H. Hirose, S. Futaki, S. Matile, H. Riezman, J. Am. Chem. Soc. 2013, 135, 9295; h) M. Song, J.-S. Kim, L. Liu, M. Husain, A. Vázquez-Torres, Cell Rep. 2016, 14, 2901.

[2] a) S. Wang, H. Kohn, J. Med. Chem. 1999, 42, 788; b) T. T. Conway, E. G. DeMaster, D. J. W. Goon, F. N. Shirota, H. T. Nagasawa, J. Med Chem. 1999, 42, 4016; c) K. C. Nicolaou, R. Hughes, J. A. Pfefferkorn, S. Barluenga, A. J. Roecker, Chem. Eur. J. 2001, 7, 4280; d) S. A Caldarelli, M. Hamel, J.-F. Duckert, M. Ouattara, M. Calas, M. Maynadier, S. Wein, C. Périgaud, A. Pellet, H. J. Vial, S. Peyrottes, J. Med. Chem. 2012, 55, 4619.

[3] a) E. Block, S. Ahmad, J. L. Catalfamo, M. K. Jain, R. Apitz-Castro, J. Am. Chem. Soc. 1986, 108, 7045; b) E. Block, R. lyer, S. Grisoni, C. Saha, S. Belman, F. P. Lossing, J. Am. Chem. Soc. 1988, 110, 7813; c) E. Block, T. Bayer, S. Naganathan, S.-H. Zhao, J. Am. Chem. Soc 1996, 118, 2799; d) F. S. Hanschen, E. Lamy, M. Schreiner, S. Rohn Angew. Chem. Int. Ed. 2014, 53, 11430; Angew. Chem. 2014, 126, 11614.

[4] For reviews, see: a) C.-S. Jiang, W. E. G. Mgller, H. C. Schröder, Y.-W. Guo, Chem. Rev. 2012, 112, 2179; For representative reports, see: b) B. Ren, G. Tibbelin, D. Pascale, M. Rossi, S. Bartolucci, R. Ladenstein, Nat. Struct. Mol. Biol. 1998, 5, 602; c) R. X. Tan, P. R. Jensen, P. G. Williams, W. Fenical, J. Nat. Prod. 2004, 67, 1374; d) K. C. Nicolaou, M. Lu, S. Totokotsopoulos, P. Heretsch, D. Giguère, Y. P. Sun, D. Sarlah, T. H. Nguyen, I. C. Wolf, D. F. Smee, C. W. Day, S. Bopp, E. A. Winzeler, J. Am. Chem. Soc. 2012, 134, 17320; e) D. H. Scharf, A. Habel, T. Heinekamp, A. A. Brakhage, C. Hertweck, J. Am. Chem. Soc 2014, 136, 11674; f) P. Chankhamjon, D. Boettger-Schmidt, K. Scherlach, B. Urbansky, G. Lackner, D. Kalb, H.-M. Dahse, D. Hoffmeister, C. Hertweck, Angew. Chem. Int. Ed. 2014, 53, 13409; Angew. Chem. 2014, 126, 13627.

[5] a) E. Brzezinska, A. L. Ternay, J. Org. Chem. 1994, 59, 8239; b) D. H. R. Barton, R. H. Hesse, A. C. O'Sullivan, M. Pechet, J. Org. Chem. 1991, 56, 6697; c) M. Bao, M. Shimizu, Tetrahedron 2003, 59, 9655; d) R. Hunter, M. Caira, N. Stellenboom, J. Org. Chem. 2006, 71, 8268; e) M. Musiejuk, D. Witt, Org. Prep. Proced. Int. 2015, 47, 95; f) M. Wang, X. Jiang, Top. Curr. Chem. (Z) 2018, 376, 14.
[6] a) J. Yuan, C. Liu, A. Lei, Org. Chem. Front. 2015, 2, 677; b) P. Huang P. Wang, S. Tang, Z. Fu, A. Lei, Angew. Chem. Int. Ed. 2018, 57, 8115; Angew. Chem. 2018, 130, 8247; c) X. Qiu, X. Yang, Y. Zhang, S. Song, N. Jiao, Org. Chem. Front. 2019, 6, 2220.

[7] M. Arisawa, M. Yamaguchi, J. Am. Chem. Soc. 2003, 125, 6624.

[8] a) X. Xiao, M. Feng, X. Jiang, Angew. Chem. Int. Ed. 2016, 55, 14121; Angew. Chem. 2016, 128, 14327; b) Z. Dai, X. Xiao, X. Jiang, Tetrahedron, 2017, 73, 3702

[9] J. Zou, J. Chen, T. Shi, Y. Hou, F. Cao, Y. Wang, X. Wang, Z. Jia, Q. Zhao, Z. Wang, ACS Catal. 2019, 9, 11426.

[10] a) W. Wang, Y. Lin, Y. Ma, C.-H. Tung, Z. Xu, Org. Lett. 2018, 20, 2956; b) W. Wang, Y. Lin, Y. Ma, C. Tung, Z. Xu, Org. Lett. 2018, 20, 3829; c) J. Qi, F. Wei, S. Huang, C.-H. Tung, Z. Xu, Angew. Chem. Int. Ed. 2021, 60, 4561; Angew. Chem. 2021, 133, 4611.

[11] For review, see: a) A. Roglans, A. Pla-Quintana, M. Moreno-Mañas, Chem. Rev. 2006, 106, 4622; b) D. P. Hari, B. König, Angew. Chem Int. Ed. 2013, 52, 4734; Angew. Chem. 2013, 125, 4832; c) F. Mo, D Qiu, Y. Zhang, J. Wang, Acc. Chem. Res. 2018, 51, 496; d) F. Mo, D Qiu, L. Zhang, J. Wang, Chem. Rev. 2021, DOI 10.1021/acs.chemrev.0c01030

[12] For selected examples of Ar-SR formation through aryl diazonium salts see: a) X. Wang, G. D. Cuny, T. Noël, Angew. Chem. Int. Ed. 2013, 52 7860; Angew. Chem. 2013, 125, 8014; b) M. Majekz, A. Jacobi von Wangelin, Chem. Commun. 2013, 49, 5507; c) Y. Li, W. Xie, X. Jiang Chem. Eur. J. 2015, 21, 16059; d) L. Zhang, P. Zhang, X. Li, J. Xu, G. Tang, Y. Zhao, J. Org. Chem. 2016, 81, 5588; e) N. Naveen, S. Sengupta, S. Chandrasekaran, J. Org. Chem. 2018, 83, 3562; f) S Dutta, A. Saha, Org. Biomol. Chem. 2019, 17, 9360; For selected examples of $\mathrm{Ar}-\mathrm{SR}_{\mathrm{f}}$ formation through aryl diazonium salts, see: $\mathrm{g}$ ) D. J. Adams, A. Goddard, J. H. Clark, D. J. Macquarrie, Chem. Commun 2000, 987; h) G. Danoun, B. Bayarmagnai, M. F. Gruenberg, L. J. Gooßen, Chem. Sci. 2014, 5, 1312; i) B. Bayarmagnai, C. Matheis, E. Risto, L. J. Gooßen, Adv. Synth. Catal. 2014, 356, 2343; j) B Bayarmagnai, C. Matheis, K. Jouvin, L. J. Gooßen, Angew. Chem. Int. Ed. 2015, 54, 5753; Angew. Chem. 2015, 127, 5845; k) J. Wu, Y. Gu X. Leng, Q. Shen, Angew. Chem. Int. Ed. 2015, 54, 7648; Angew. Chem. 2015, 127, 7758; I) C. Matheis, V. Wagner, L. J. Gooßen, Chem Eur. J. 2016, 22, 79; m) C. Matheis, B. Bayarmagnai, K. Jouvin, L. J. Gooßen, Org. Chem. Front. 2016, 3, 949; n) D. Koziakov, M. Majek, A Jacobi von Wangelin, Eur. J. Org. Chem. 2017, 6722; o) X. Zhao, X Zheng, M. Tian, Y. Tong, B. Yang, X. Wei, D. Qiua, K. Lu, Org. Chem Front. 2018, 5, 2636; p) C. Ghiazza, C. Monnereau, L. Khrouz, T. Billard, A. Tlili, Synthesis 2019, 51, 2865

[13] For selected examples of access to aryl sulphones and sulfonimidamide derivatives through aryl diazonium salts, see: a) D. Zheng, Y. An, Z. Li, J. Wu, Angew. Chem. Int. Ed. 2014, 53, 2451; Angew. 
Chem. 2014, 126, 2483; b) D. Zheng, J. Yu, J. Wu, Angew. Chem. Int Ed. 2016, 55, 11925; Angew. Chem. 2016, 128, 12104; c) F. Liu, J.-Y. Wang, P. Zhou, G. Li, W.-J. Hao, S.-J. Tu, B. Jiang, Angew. Chem. Int Ed. 2017, 56, 15570; Angew. Chem. 2017, 129, 15776; d) D. H. Kim, J. Lee, A. Lee, Org. Lett. 2018, 20, 764; e) M. Bremerich, C. M. Conrads, T. Langletz, C. Bolm, Angew. Chem. Int. Ed. 2019, 58, 19014; Angew. Chem. 2019, 131, 19190; f) Y. Liu, D. Yu, Y. Guo, J.-C. Xiao, Q.-Y. Chen, C. Liu, Org. Lett. 2020, 22, 2281; g) S. Ye, M. Yang, J. Wu Chem. Commun. 2020, 56, 4145 .

[14] For selected examples of $\mathrm{C}-\mathrm{H}$ bond functionalization assisted by amine group of anilines, see: a) H. He, W.-B. Liu, L.-X. Dai, S.-L. You, J. Am Chem. Soc. 2009, 131, 8346; b) K.-Y. Ye, H. He, W.-B. Liu, L.-X. Dai, G. Helmchen, S.-L. You, J. Am. Chem. Soc. 2011, 133, 19006; c) Z. Liang, L. Ju, Y. Xie, L. Huang, Y. Zhang, Chem. Eur. J. 2012, 18, 15816; d) C. Tang, N. Jiao, J. Am. Chem. Soc. 2012, 134, 18924; e) S P. Midya, M. K. Sahoo, V. G. Landge, P. R. Rajamohanan, E. Balaraman, Nat. Commun. 2015, 6, 8591; f) M. R. Smith, III, R. Bisht, C. Haldar, G. Pandey, J. E. Dannatt, B. Ghaffari, R. E. Maleczka, Jr, B. Chattopadhyay, ACS Catal. 2018, 8, 6216; g) K. Naksomboon, J. Poater, F. M. Bickelhaupt, M. Á. Fernández-Ibáñez, J. Am. Chem. Soc. 2019, 141, 6719

[15] For selected reviews, see: a) D. A. Everson, D. J. Weix, J. Org. Chem 2014, 79, 4793; b) D. J. Weix, Acc. Chem. Res. 2015, 48, 1767; c) J. Gu, X. Wang, W. Xue, H. Gong, Org. Chem. Front. 2015, 2, 1411; d) C. E. I. Knappke, S. Grupe, D. Gartner, M. Corpet, C. Gosmini, A. Jacobi von Wangelin, Chem. Eur. J. 2014, 20, 6828.

[16] For selected examples of reductive cross couplings to form the $\mathrm{C}\left(\mathrm{sp}^{2}\right)-\mathrm{C}$ bond, see: a) D. A. Everson, R. Shrestha, D. J. Weix, J. Am. Chem. Soc. 2010, 132, 920; b) X. Li, Z. Feng, Z.-X. Jiang, X. Zhang, Org. Lett. 2015, 17, 5570; c) N. T. Kadunce, S. E. Reisman, J. Am. Chem. Soc. 2015, 137, 10480; d) M. O. Konev, L. E. Hanna, E. R. Jarvo, Angew. Chem. Int. Ed. 2016, 55, 6730; Angew. Chem. 2016, 128, 6842; e) K. E. Poremba, N. T. Kadunce, N. Suzuki, A. H. Cherney, S. E. Reisman, J. Am. Chem. Soc. 2017, 139, 5684; f) L. Peng, Y. Li, Y. Li, W. Wang, H. Pang, G. Yin, ACS Catal. 2018, 8, 310; g) T. Suga, Y. Ukaji, Org. Lett 2018, 20, 7846; h) X. Wang, G. Ma, Y. Peng, C. E. Pitsch, B. J. Moll, T. D. Ly, X. Wang, H. Gong, J. Am. Chem. Soc. 2018, 140, 14490; i) J. Liao, C. H. Basch, M. E. Hoerrner, M. R. Talley, B. P. Boscoe, J. W. Tucker, M. R. Garnsey, M. P. Watson, Org. Lett. 2019, 21, 2941; j) L. Huang, L. K. G. Ackerman, K. Kang, A. M. Parsons, D. J. Weix, J. Am Chem. Soc. 2019, 141, 10978; k) Y. Meng, M. Wang, X. Jiang, Angew. Chem. Int. Ed. 2020, 59, 1346; Angew. Chem. 2020, 132, 1362; I) H. Guan, Q. Zhang, P. J. Walsh, J. Mao, Angew. Chem. Int. Ed. 2020, 59, 5172; Angew. Chem. 2020, 132, 5210; m) B. L. Truesdell, T. B. Hamby, C. S. Sevov, J. Am. Chem. Soc. 2020, 142, 5884; n) G. S Kumar, A. Peshkov, A. Brzozowska, P. Nikolaienko, C. Zhu, M
Rueping, Angew. Chem. Int. Ed. 2020, 59, 6513; Angew. Chem. 2020 132, 6575; o) K.-J. Jiao, D. Liu, H.-X. Ma, H. Qiu, P. Fang, T.-S. Mei, Angew. Chem. Int. Ed. 2020, 59, 6520; Angew. Chem. 2020, 132, 6582 p) J. Tang, L. L. Liu, S. Yang, X. Cong, M. Luo, X. Zeng, J. Am. Chem Soc. 2020, 142, 7715; q) T. J. Steiman, J. Liu, A. Mengiste, A. G. Doyle J. Am. Chem. Soc. 2020, 142, 7598; r) D. J. Charboneau, E. L. Barth N. Hazari, M. R. Uehling, S. L. Zultanski, ACS Catal. 2020, 10, 12642; s) J. Tang, F. Fan, X. Cong, L. Zhao, M. Luo, X. Zeng, J. Am. Chem. Soc. 2020, 142, 12834; t) W. Miao, C. Ni, P. Xiao, R. Jia, W. Zhang, J. Hu, Org. Lett. 2021, 23, 711; u) Z. Li, W. Sun, X. Wang, L. Li, Y. Zhang C. Li, J. Am. Chem. Soc. 2021, 143, 3536; v) I. Nohira, N. Chatani, ACS Catal. 2021, 11, 4644; w) Y. Min, J. Sheng, J.-L. Yu, S.-X. Ni, G Ma, H. Gong, X.-S. Wang, Angew. Chem. Int. Ed. 2021, 60, 9947; Angew. Chem. 2021, 133, 10035

[17] For selected examples of SET reduction of aryl diazonium salts to generate the corresponding aryl radicals, see: a) D. Kalyani, K. B. McMurtrey, S. R. Neufeldt, M. S. Sanford, J. Am. Chem. Soc. 2011, 133, 18566; b) J.-J. Dai, C. Fang, B. Xiao, J. Yi, J. Xu, Z.-J. Liu, X. Lu, L. Liu, Y. Fu, J. Am. Chem. Soc. 2013, 135, 8436; c) D. Qiu, H. Meng, L. Jin, S. Wang, S. Tang, X. Wang, F. Mo, Y. Zhang, J. Wang, Angew. Chem. Int. Ed. 2013, 52, 11581; Angew. Chem. 2013, 125, 11795; d) D P. Hari, T. Hering, B. König, Angew. Chem. Int. Ed. 2014, 53, 725; Angew. Chem. 2014, 126, 743; e) M. Hartmann, A. Studer, Angew. Chem. Int. Ed. 2014, 53, 8180; Angew. Chem. 2014, 126, 8319; f) W. Guo, L.-Q. Lu, Y. Wang, Y.-N. Wang, J.-R. Chen, W.-J. Xiao, Angew. Chem. Int. Ed. 2015, 54, 2265; Angew. Chem. 2015, 127, 2293; g) L. Huang, D. Hackenberger, L. J. Gooßen, Angew. Chem. Int. Ed. 2015 54, 12607; Angew. Chem. 2015, 127, 12798; h) S. Kindt, K. Wicht, M R. Heinrich, Angew. Chem. Int. Ed. 2016, 55, 8744; Angew. Chem. 2016, 128, 8886; i) C. Ghiazza, V. Debrauwer, C. Monnereau, L. Khrouz, M. Médebielle, T. Billard, A. Tlili, Angew. Chem. Int. Ed. 2018 57, 11781; Angew. Chem. 2018, 130, 11955; j) S. Yang, M. Chen, P. Tang, Angew. Chem. Int. Ed. 2019, 58, 7840; Angew. Chem. 2019, 131 7922; k) P. Wang, Z. Yang, Z. Wang, C. Xu, L. Huang, S. Wang, H. Zhang, A. Lei, Angew. Chem. Int. Ed. 2019, 58, 15747; Angew. Chem. 2019, 131, 15894

[18] a) T. Sandmeyer, Ber. Dtsch. Chem. Ges. 1884, 17, 1633; b) T Sandmeyer, Ber. Dtsch. Chem. Ges. 1884, 17, 2650

[19] a) M. P. Doyle, B. Siegfried, J. F. Dellaria, J. Org. Chem. 1977, 42, 2426; b) M. P. Doyle, J. F. Dellaria, B. Siegfried, S. W. Bishop, J. Org Chem. 1977, 42, 3494.

[20] For applications of 2b, see: a) K. C. Nicolaou, R. Li, Z. Lu, E. N. Pitsinos, L. B. Alemany, J. Am. Chem. Soc. 2018, 140, 8091; b) W.-C Gao, J. Tian, Y.-Z. Shang, X. Jiang, Chem. Sci., 2020, 11, 3903; also see: reference 9; For applications of alkylO-SSR', see: c) X. Xiao, J. Xue, X. Jiang, Nat. Commun. 2018, 9, 2191; d) J. Xue, X. Jiang, Nat 
Commun. 2020, 11, 4170; e) Q. Zhang, Y. Li, L. Zhang, S. Luo, Angew. Chem. Int. Ed. 2021, 60, 10971; Angew. Chem. 2021, 133, 11066.

[21] Z. Wu, D. A. Pratt, J. Am. Chem. Soc. 2020, 142, 10284.

[22] While this manuscript was in preparation, alkyl radical substitution with Ts-SSR reported by Pratt group, see: Z. Wu, D. A. Pratt, Angew. Chem. Int. Ed. 2021, doi.org/10.1002/anie.202104595, accepted articles. 